\title{
CLASSNOTEBOOK: PORTOFOLIO DIGITAL DALAM PEMBELAJARAN
}

Eric Kunto Aribowo, S.S., M.A.

1. Kunjungi laman https://portal.office.com lalu masukkan akun dan kata sandi.

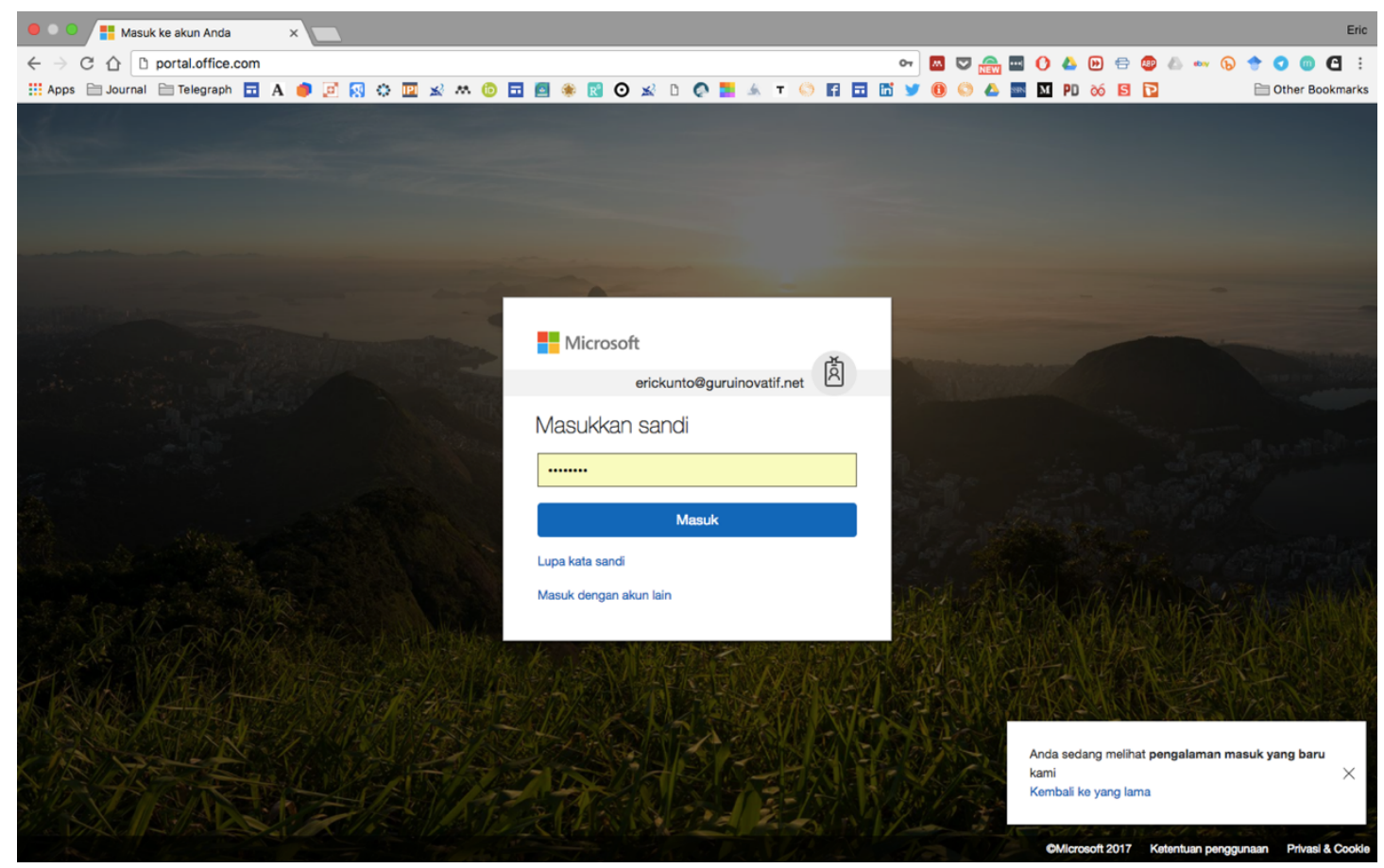

2. Pilih aplikasi Class Notebook dengan logo $\mathrm{N}$ yang diikuti dengan emblem piagam.

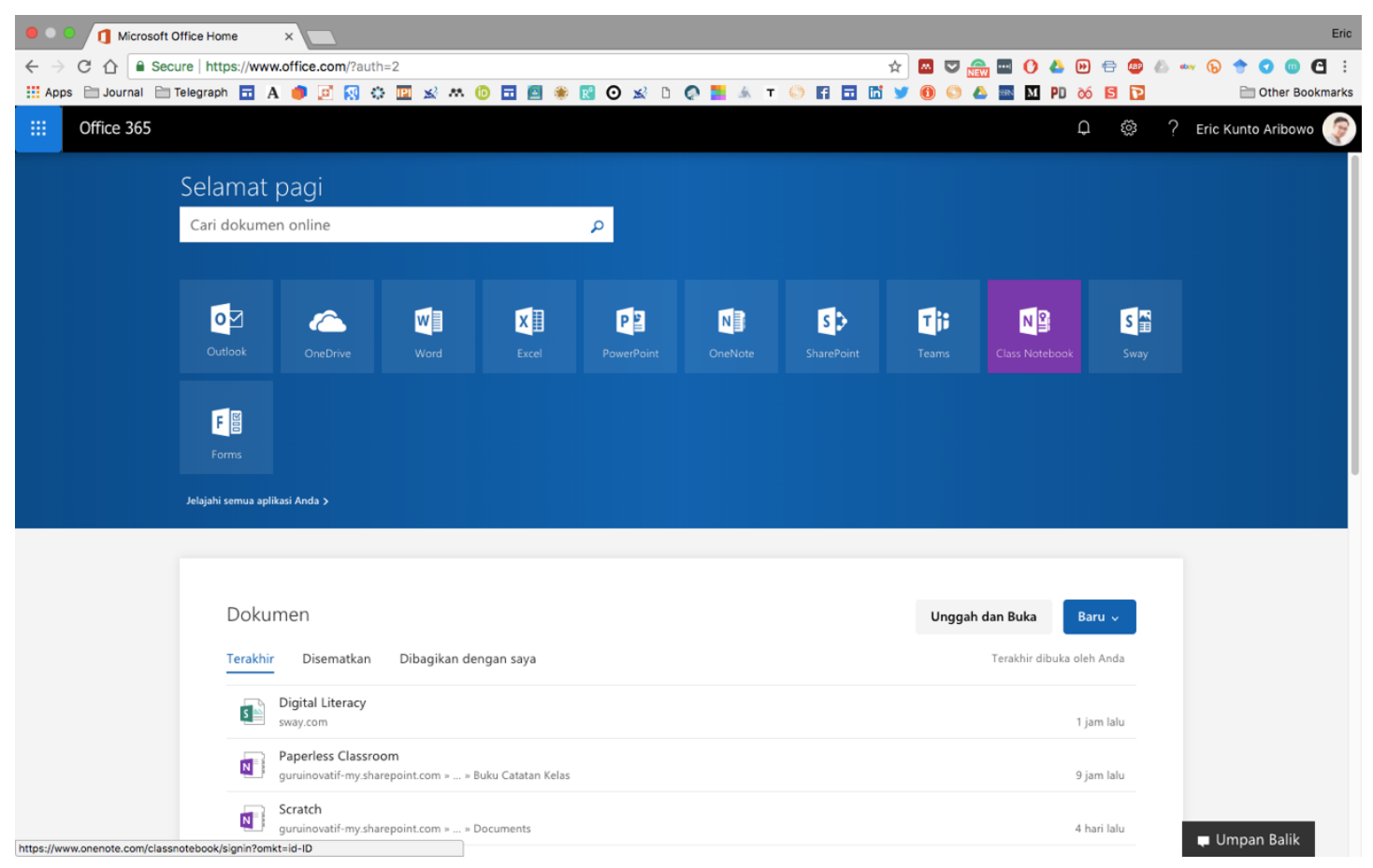


3. Untuk membuat kelas baru, pilih "Buat buku catatan kelas"

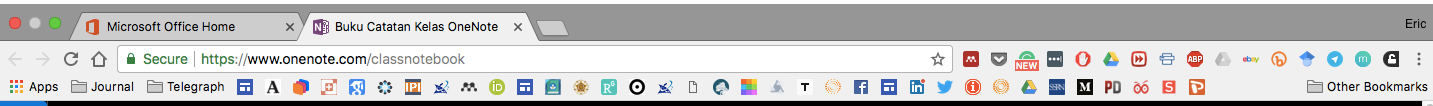

\section{Selamat datang di Buku Catatan Kelas OneNote} Kami akan membantu Anda membuat buku catatan yang dapat Anda gunakan di dalam ruang kelas
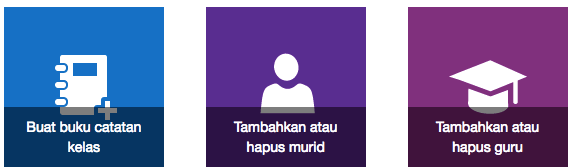

4. Pertama-tama Anda akan diminta untuk menuliskan nama kelas Anda.

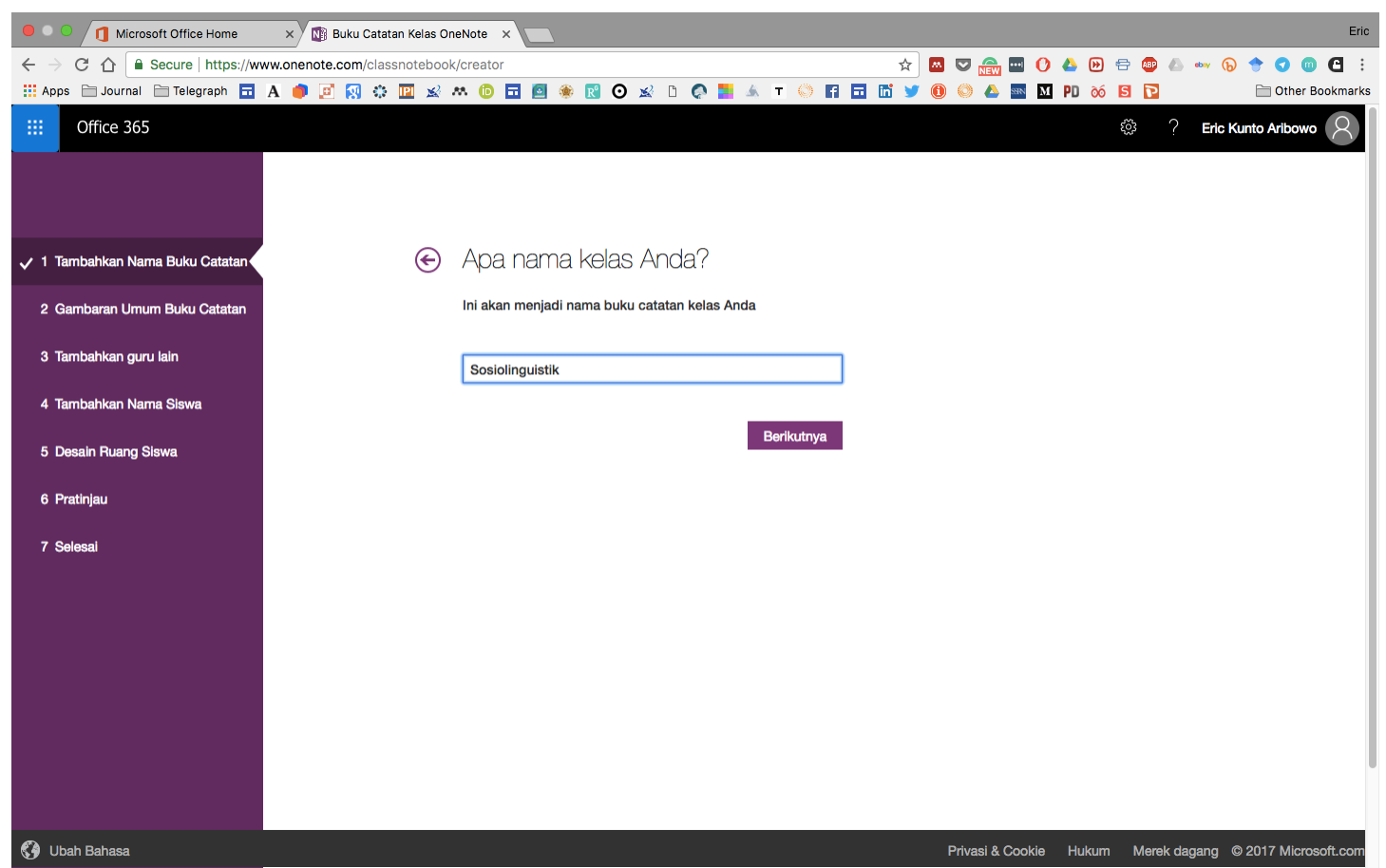


5. Secara default isi catatan kelas akan terdiri dari 3 bagian besar: "Ruang Kolaborasi", "Pustaka Konten", dan "Buku Catatan Siswa". Baca dengan seksama perbedaan ketiga bagian tersebut!

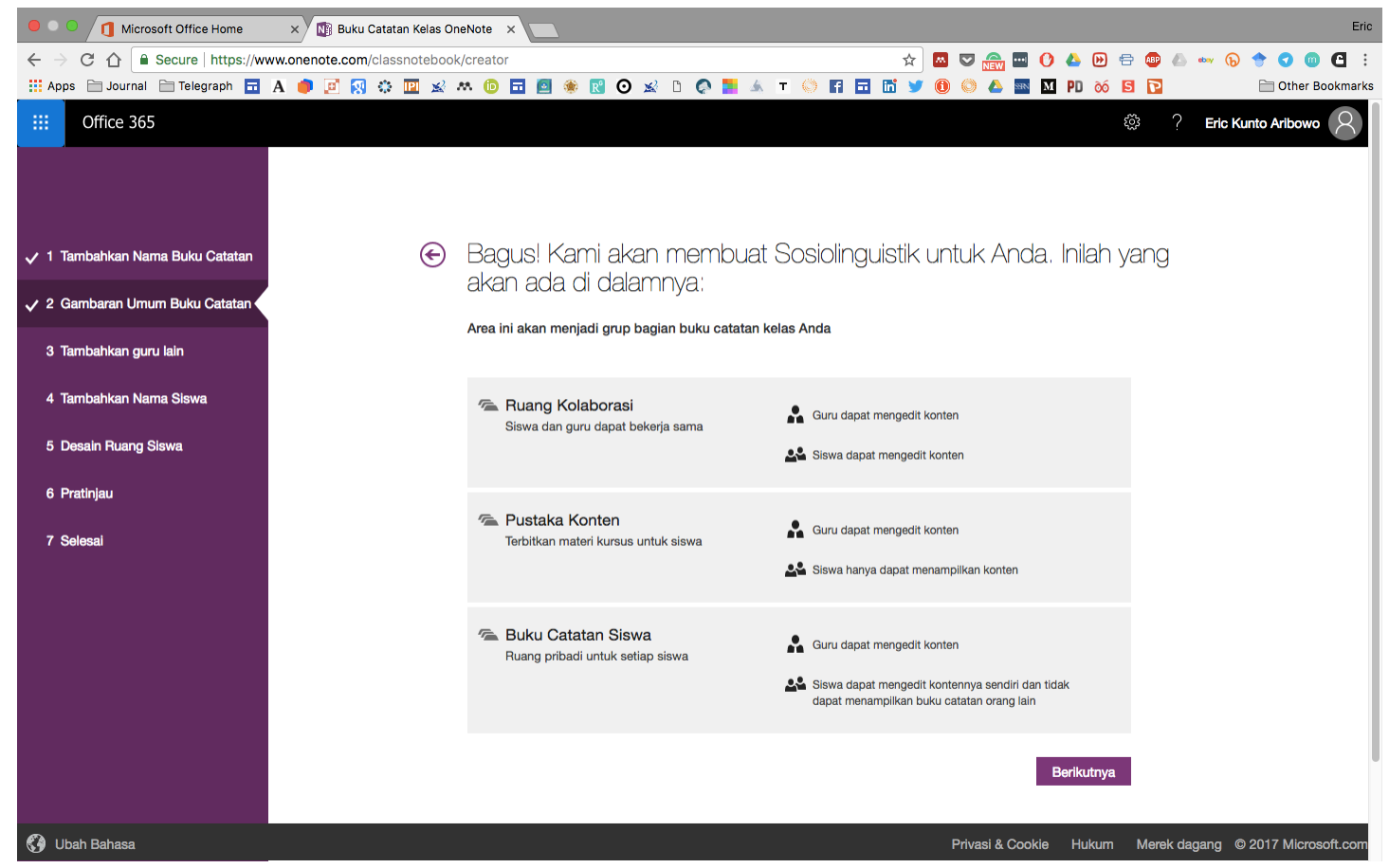

6. Selanjutnya, tambahkan guru atau dosen apabila mata pelajaran/kuliah diampu oleh beberapa guru atau dosen. Anda dapat melewati proses ini apabila mata pelajaran/kuliah hanya diampu oleh satu orang.

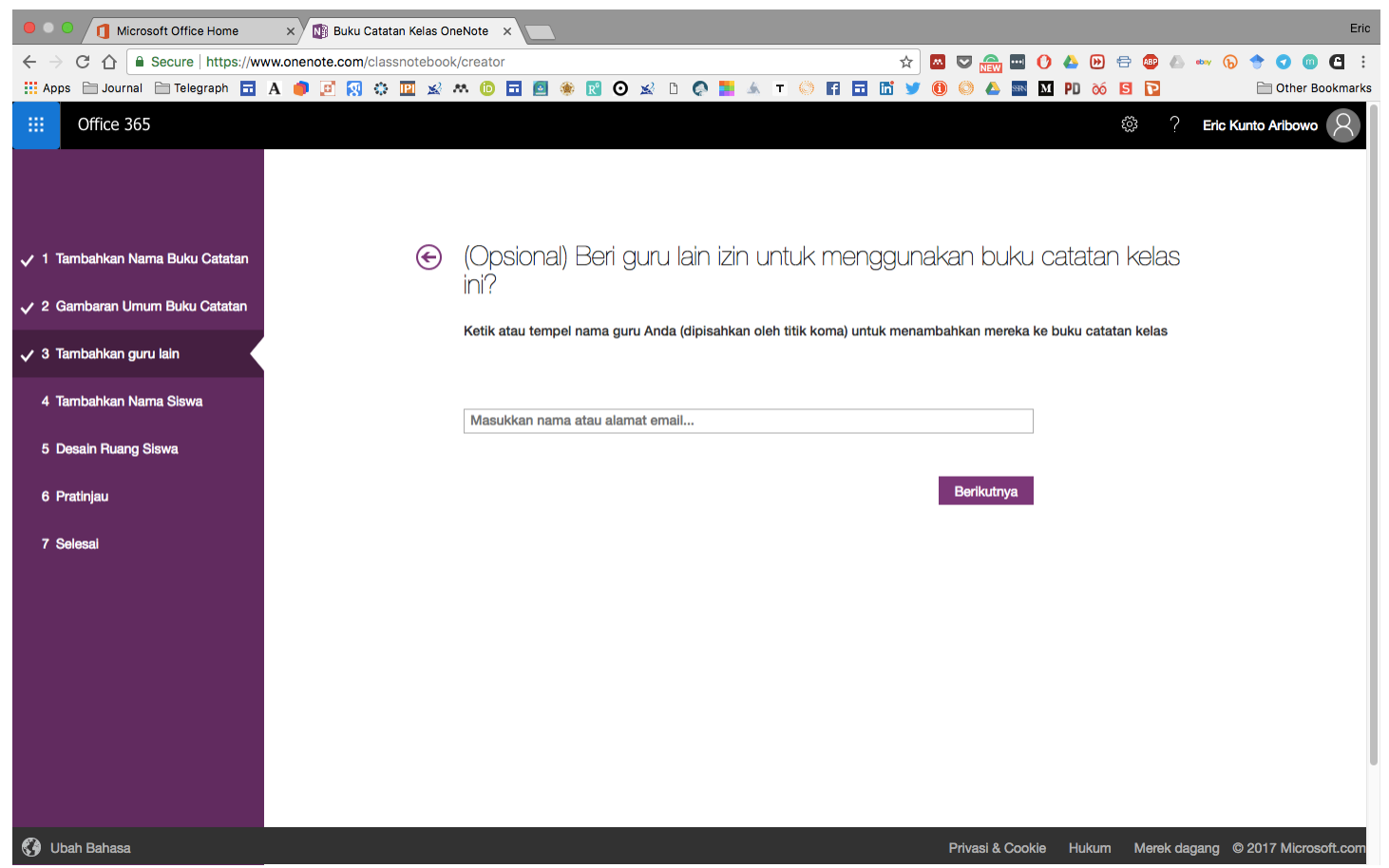


7. Masukkan nama (maha)siswa Anda satu per satu dengan cara mengetik nama mereka. Nama-nama yang muncul hanya nama-nama yang telah memiliki akun Office 365. Anda dapat memasukkan nama secara acak (tidak harus urut abjad).

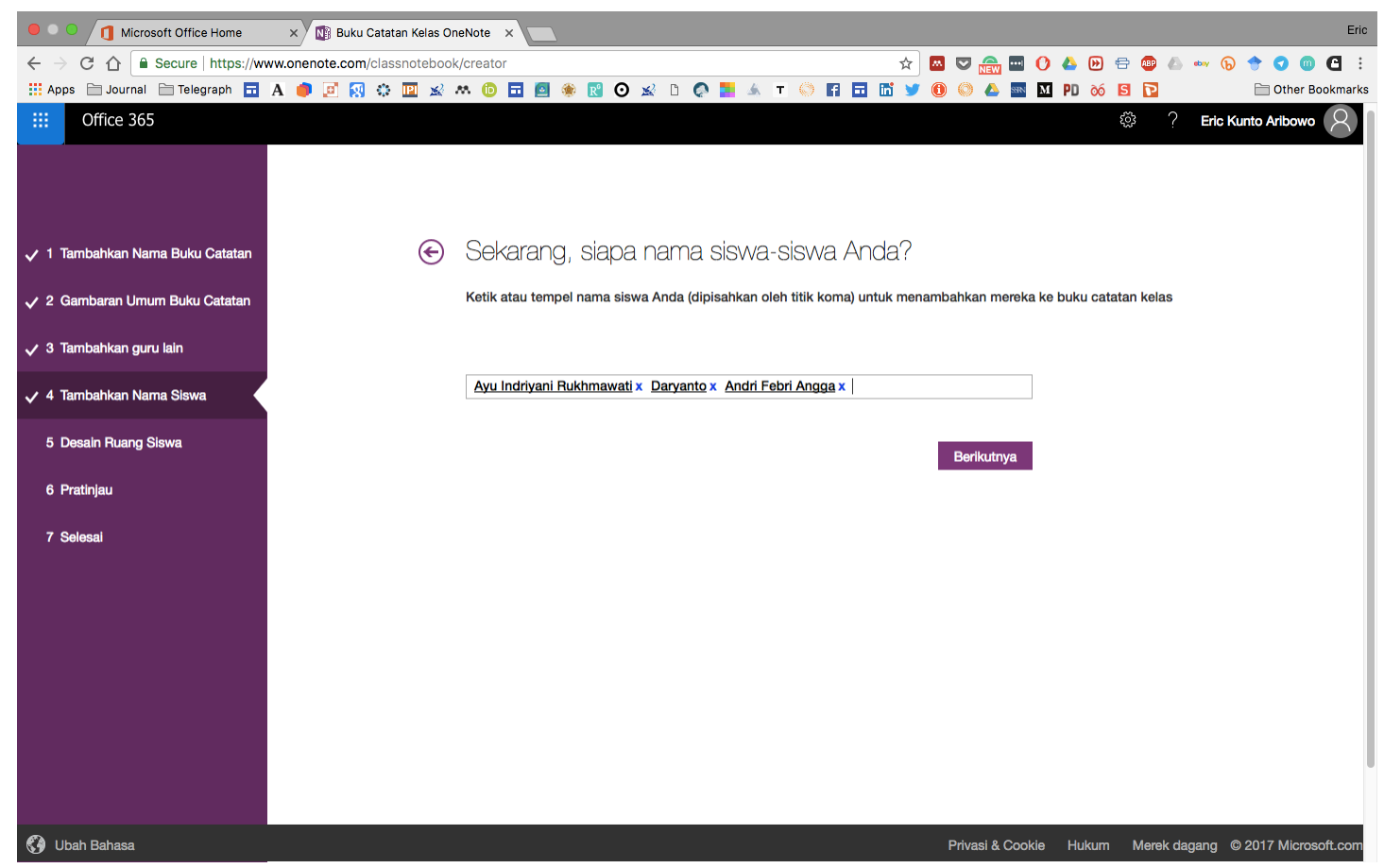

8. "Ruang Siswa" merupakan "Section" yang akan muncul di tiap-tiap catatan siswa. Hanya guru/dosen yang dapat menambah/menghapus "Section". Sesuaikan "Section" dengan kebutuhan mata pelajaran/kuliah Anda. Untuk menambahkan, pilih "Tambahkan lainnya". Anda dapat pula mengedit ketika "Section" ini telah dibuat.

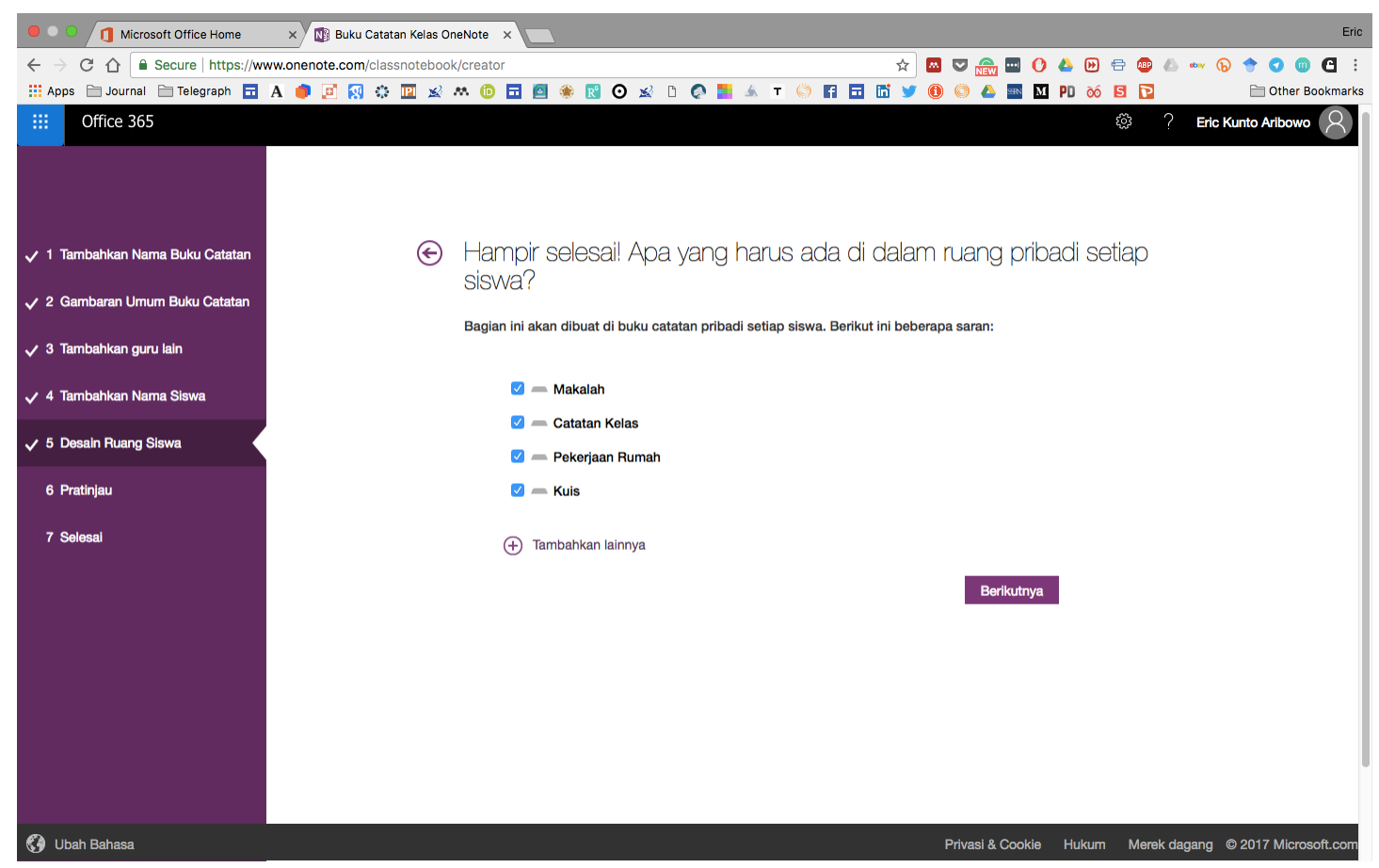


9. Tambahkan Section default di catatan siswa, misalnya "Jurnal Ilmiah".

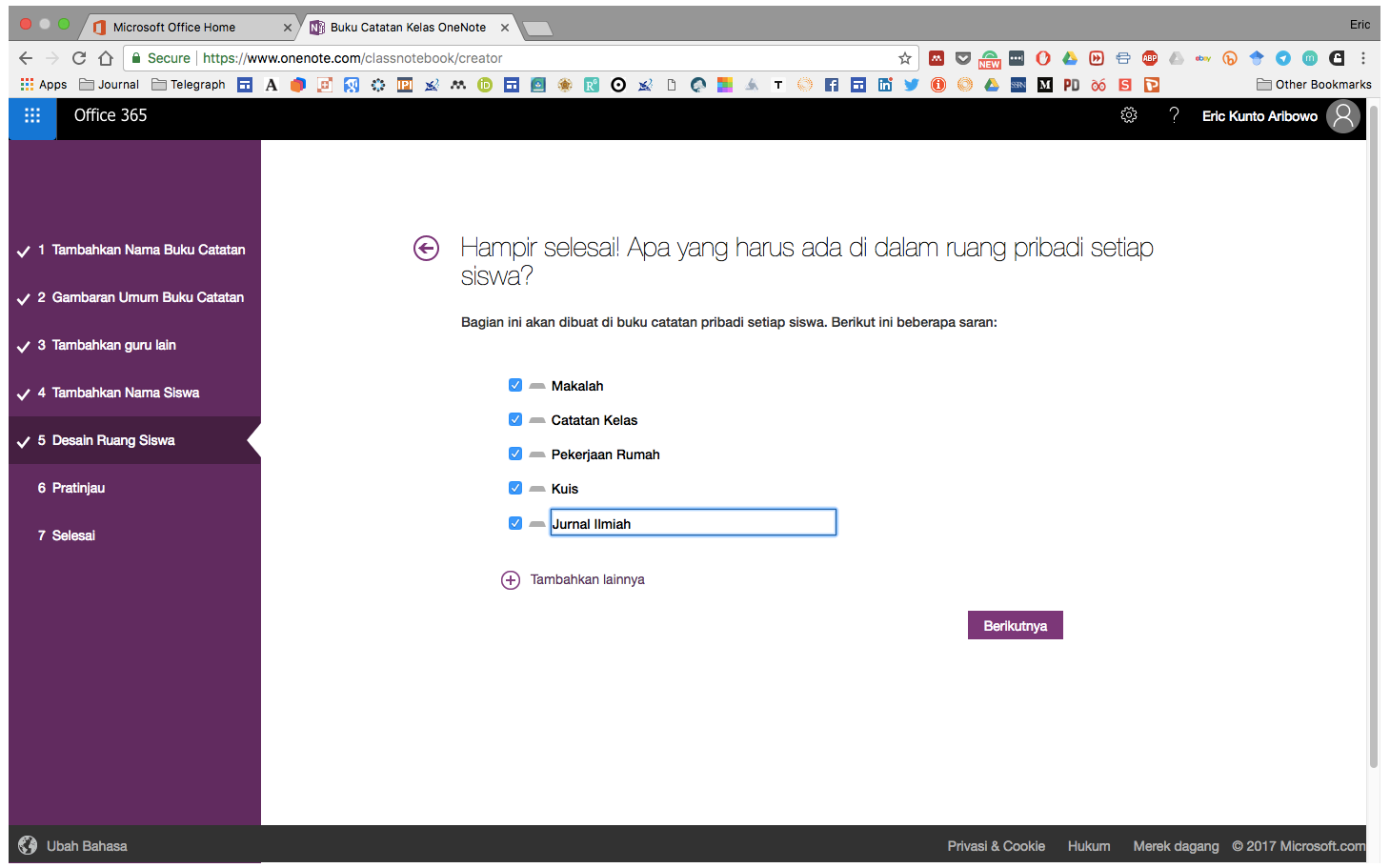

10. Tampilan preview buku catatan siswa.

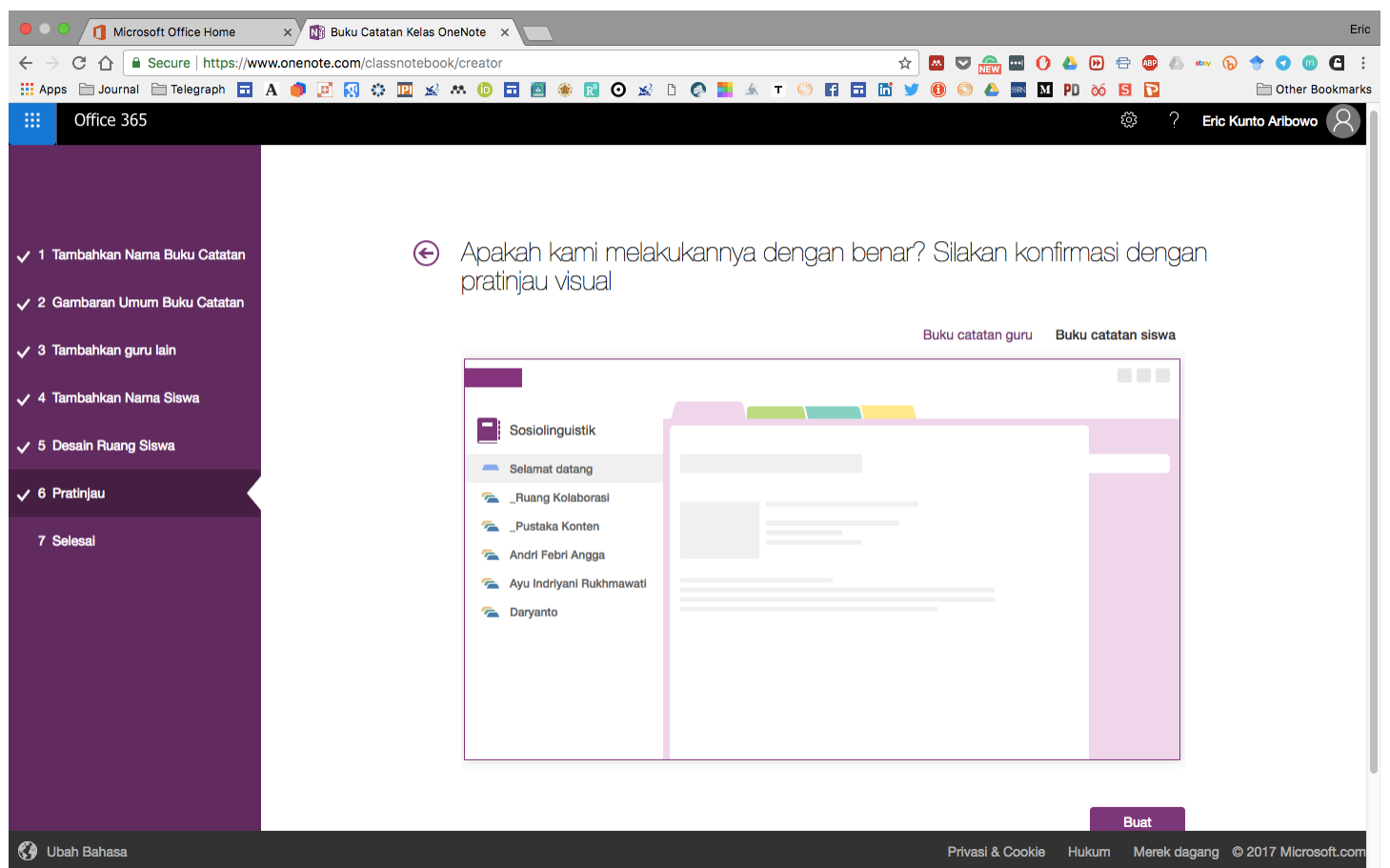


11. Tunggu proses pembuatan buku catatan siswa hingga selesai.

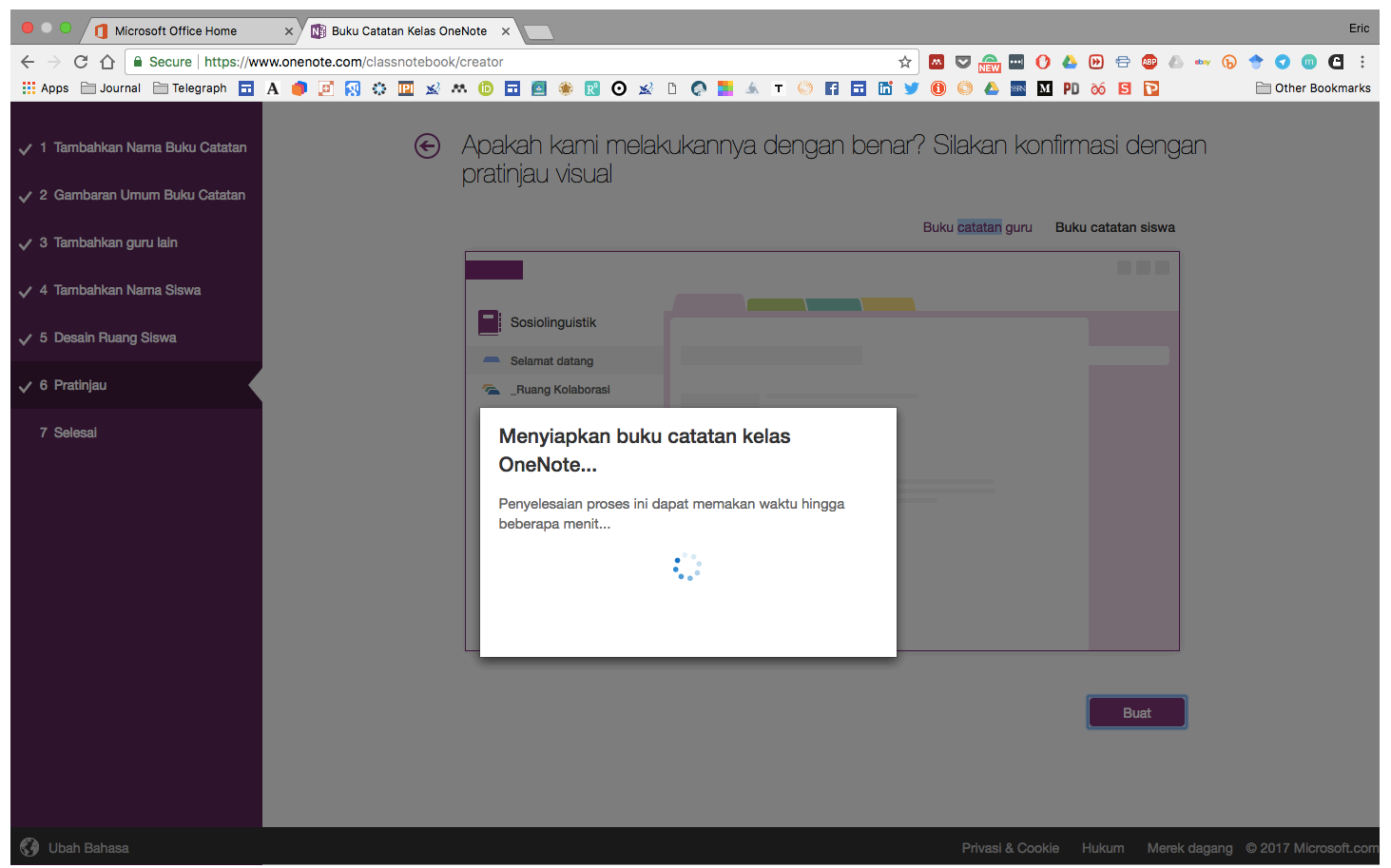

12. Selanjutnya, Anda dapat membuka buku catatan menggunakan OneNote Desktop (silakan unduh melalui https://portal.office.com ) ataupun OneNote Online.

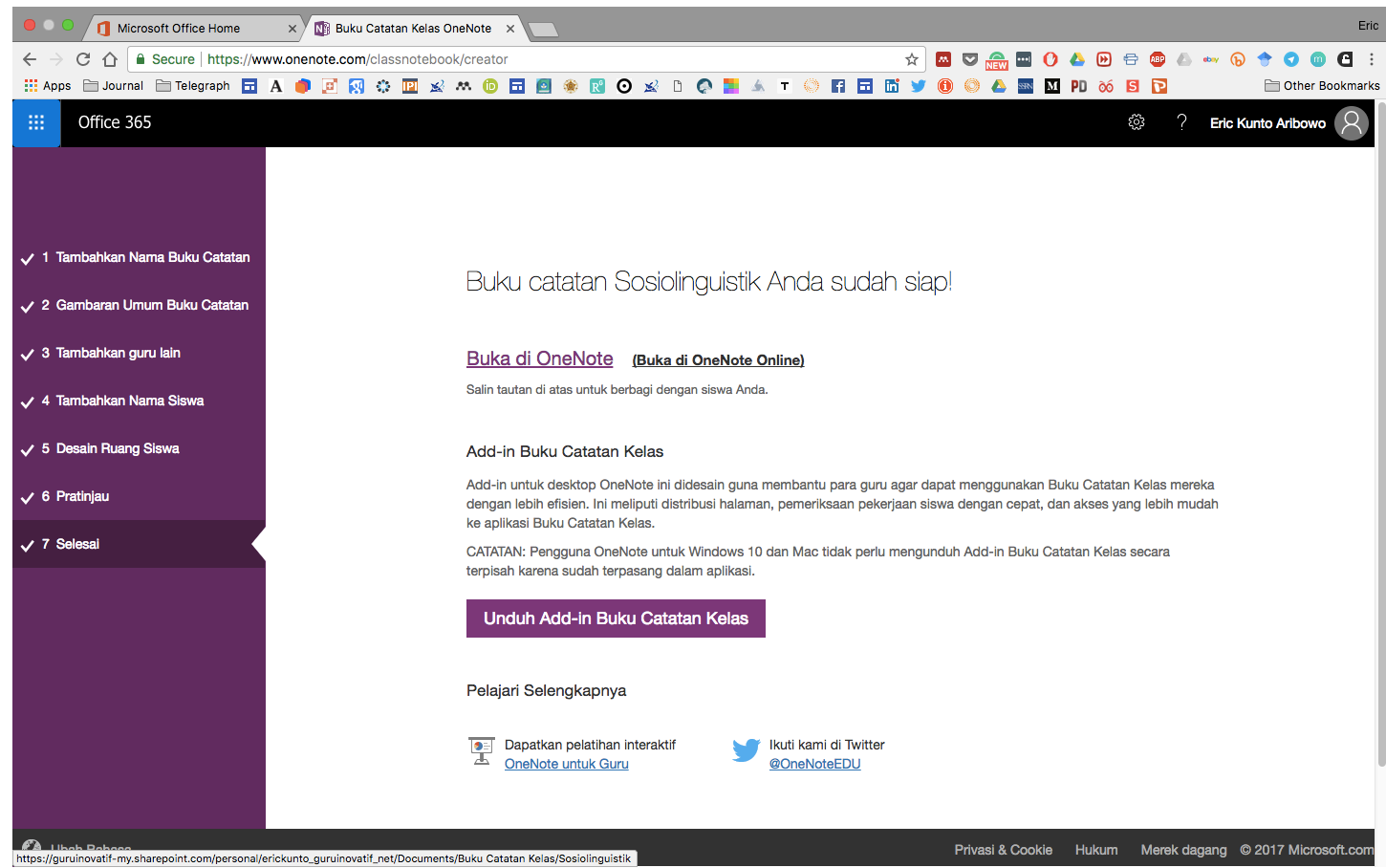


13. Tampilan OneNote Online. "Pustaka Konten" merupakan bagian yang hanya bisa diedit oleh guru, sedangkan (maha)siswa hanya dapat melihat/membaca.

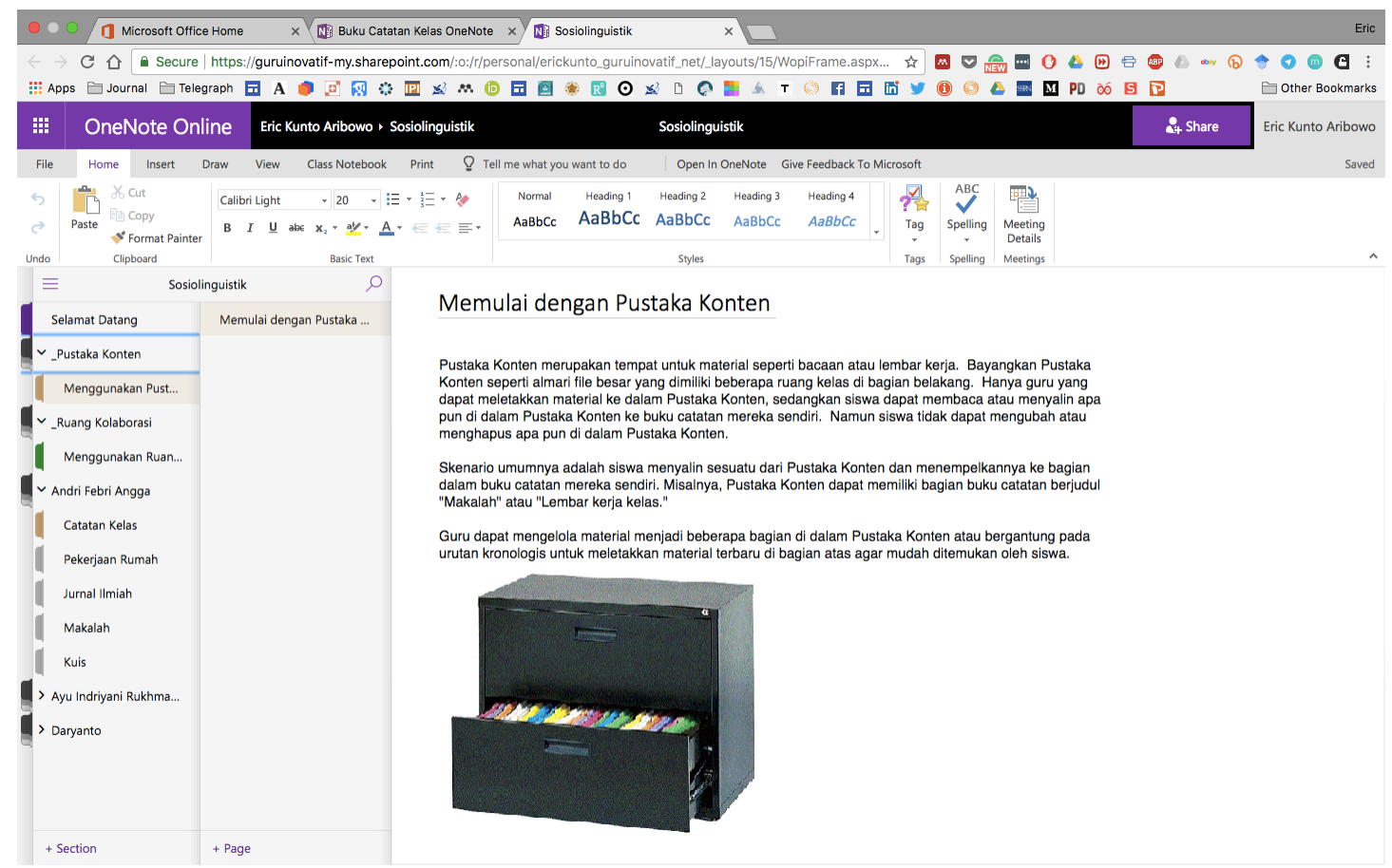

14. "Ruang Kolaborasi" merupakan bagian di mana seluruh (maha)siswa dan guru dapat melihat dan mengedit. Bagian ini dapat digunakan untuk mendapatkan umpan balik dari (maha)siswa lain atau media (maha)siswa untuk bekerja sama.

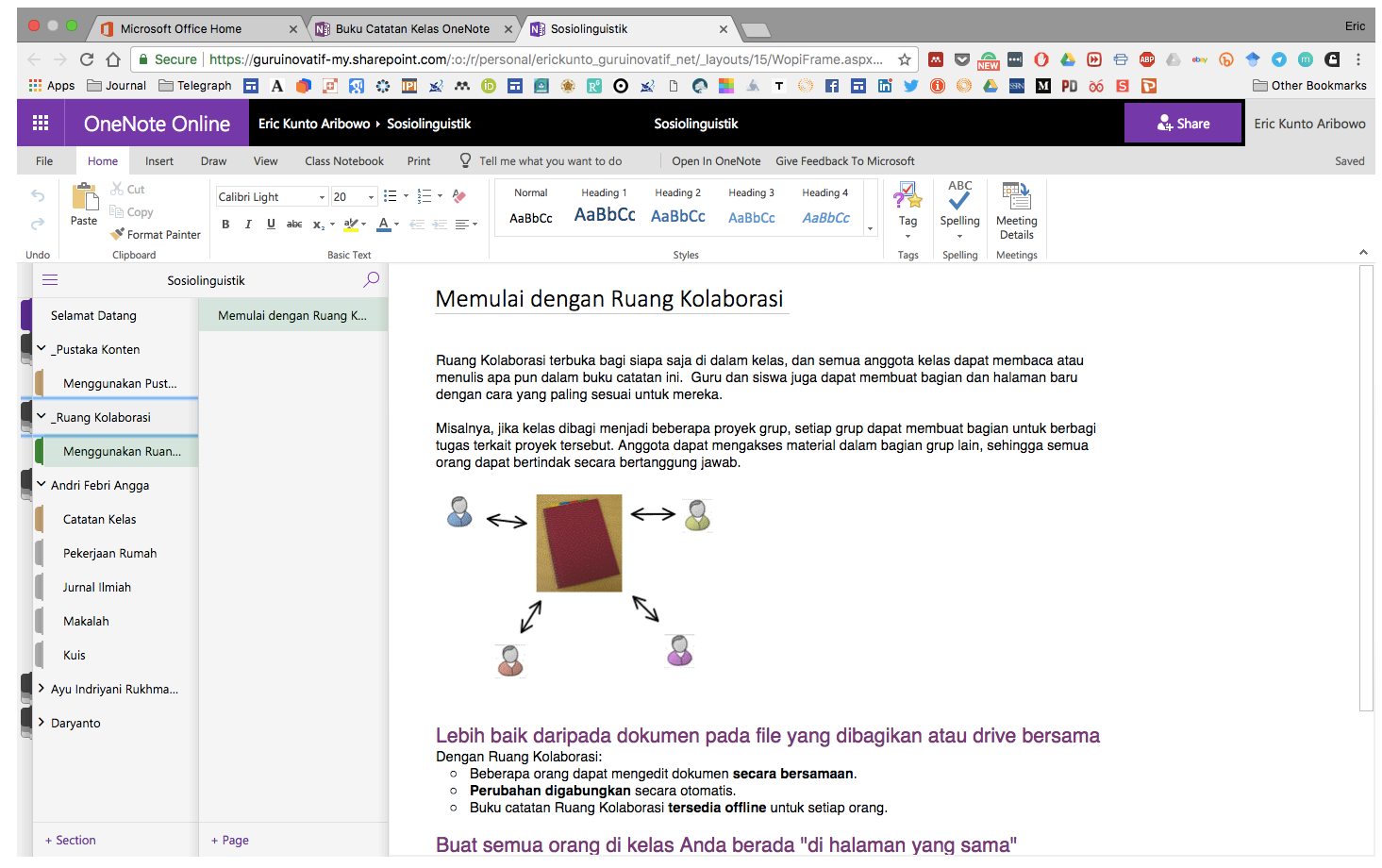




\section{TUGAS}

$\mathrm{P}$ ara peserta ToT yang berbahagia, pada kesempatan kali ini kita akan berlatih untuk berkolaborasi dalam mengerjakan sebuah proyek. Proyek yang akan kita kerjakan ialah membuat feature mengenai "10 Destinasi Wisata Prioritas Indonesia" yang telah ditetapkan oleh Presiden Joko Widodo di tahun 2016 yang lalu. Proyek ini bertujuan untuk mempromosikan 10 destinasi wisata tersebut.

Para peserta akan dibagi ke dalam 10 kelompok berdasarkan destinasi wisata. Para peserta dapat memilih anggota kelompoknya secara bebas (1 kelompok, 2 anggota). Setelah menyelesaikan proyek ini, akan dipilih 3 proyek terbaik dengan kriteria sebagai berikut.

1. Liputan yang diulas mengandung informasi yang menarik yang menggugah ketertarikan pembaca untuk mengunjungi destinasi wisata tersebut.

2. Memberikan potret gambaran yang lengkap mengenai destinasi wisata tersebut, termasuk atraksi atau wahana yang ada di dalamnya.

3. Menautkan video dari Youtube! untuk mendukung informasi yang telah diberikan.

4. Memberikan rute perjalanan dari Jakarta berikut moda transportasi yang dapat diakses, termasuk kisaran biaya yang dikeluarkan.

\section{Berikut adalah 10 Destinasi Wisata Prioritas Indonesia}

1. Danau Toba

2. Tanjung Kelayang

3. Kepulauan Seribu

4. Tanjung Lesung

5. Borobudur

6. Bromo, Tengger, Semeru

7. Mandalika

8. Wakatobi

9. Pulau Morotai

10. Labuan Bajo 